\title{
PENGARUH TEKNIK BIBLIOTERAPI UNTUK MENGUBAH KONSEP DIRI SISWA \\ (Studi Kuasi Eksperimen Pada Siswa Kelas VIII SMP Negeri 2 Tangerang)
}

\author{
Ardo Trihantoro ${ }^{1}$ \\ Dede Rahmat Hidayat ${ }^{2}$ \\ Indira Chanum ${ }^{3}$
}

\begin{abstract}
Abstrak
Penelitian ini bertujuan untuk mengetahui konsep diri siswa sebelum dan sesudah penerapan teknik biblioterapi dan mengetahui pengaruh teknik biblioterapi untuk mengubah konsep diri siswa. Penelitian dilakukan di SMP Negeri 2 Tangerang pada bulan November 2015. Penelitian ini menggunakan metode kuasi eksperimen dengan bentuk Nonequivalent Control Group Design dan menggunakan sampel sebanyak 12 orang siswa dengan penggunaan teknik biblioterapi dalam bentuk kelompok. Pengukuran pada penelitian ini dilakukan dengan menggunakan instrumen yang dikembangkan berdasarkan teori konsep diri sebanyak 59 item pernyataan yang valid dan memiliki koefisien reliabilitas sebesar 0.917 dengan kategori layak dipergunakan dalam penelitian. Berdasarkan hasil pengujian hipotesis dengan menggunakan Mann Whitney U-Test diperoleh hasil nilai asymp. Sig $=0.037$. Hipotesis penelitian diuji pada taraf signifikansi $\alpha=0.05$ atau dengan tingkat kesalahan sebesar 5\%, maka nilai Asymp. Sig $=0.037<$ nilai signifikansi $\alpha=0.05$ sehingga disimpulkan bahwa $\mathrm{H}_{0}$ ditolak dan $\mathrm{H}_{1}$ diterima. Hal tersebut berarti bahwa terjadi perubahan pada konsep diri responden kelompok eksperimen setelah diberikan biblioterapi. Berdasarkan penelitian yang telah dilakukan, teknik biblioterapi berpengaruh positif terhadap perubahan konsep diri siswa. Biblioterapi dapat diterapkan oleh guru bimbingan dan konseling di sekolah sebagai satu bentuk alternatif penanganan bagi siswa yang memiliki konsep diri negatif.
\end{abstract}

Kata Kunci: biblioterapi, konsep diri, siswa

\section{PENDAHULUAN}

Masa remaja merupakan masa individu mengalami proses peralihan dari anak-anak menjadi dewasa. Batasan remaja di Indonesia adalah usia 11 tahun sampai 24 tahun dan belum menikah. Hal tersebut menunjukkan bahwa siswa Sekolah Menengah Pertama termasuk dalam kategori usia remaja. Pada masa remaja, individu mengalami perubahan-perubahan pada dirinya seperti perubahan fisik, sikap, tingkah laku, tuntutan dari masyarakat baik yang berupa nilai, peraturan, norma dan hukum. Secara intelektual juga individu mengalami perubahan pada masa remaja. Individu yang masuk ke masa remaja akan bertambah kemampuannya dalam berpikir abstrak dan dalam mengemukakakn pendapat. Pada masa remaja, individu memiliki tugas perkembangan yang berbeda dari masa anak. Berdasarkan hal tersebut menandakan bahwa konsep diri sangat penting perannya dalam

\footnotetext{
${ }^{1}$ Mahasiswa Program Studi Bimbingan dan Konseling FIP UNJ, ardo.toro@gmail.com

${ }^{2}$ Dosen Program Studi Bimbingan dan Konseling FIP UNJ, d_r_hidayat@yahoo.com

${ }^{3}$ Dosen Program Studi Bimbingan dan Konseling FIP UNJ, indirasunito@yahoo.com
} 
merespons perubahan-perubahan tersebut karena konsep diri merupakan pondasi diri.

Fitts mendefinisikan konsep diri sebagai keseluruhan kesadaran tentang diri yang diamati, dialami dan dinilai oleh individu itu sendiri, yang meliputi dunia dalam dirinya maupun hubungannya dengan dunia di luar dirinya. Konsep diri merupakan aspek penting dalam diri seseorang, karena konsep diri merupakan kerangka acuan (frame of reference) yang digunakan oleh individu dalam berinteraksi dengan lingkungannya. Konsep diri positif sangat penting dimiliki setiap individu. Individu yang memiliki konsep diri positif akan mampu melihat potensi diri dan menerima kekurangan diri. Pandangan mengenai konsep diri berdampak kepada sikap yang ditampilkan individu. Konsep diri terbentuk tidak serta merta ada karena faktor bawaan (genetik). Konsep diri merupakan persepsi yang dimunculkan melalui proses pengalaman pribadi yang dialami seseorang. Konsep diri seseorang terbentuk melalui proses yang panjang dan bervariasi. Salah satu langkah awal seseorang mempelajari konsep diri yaitu kesadaran individu terhadap dirinya sendiri. Beberapa cara untuk memperoleh pemahaman yang baik adalah dengan membaca.

Biblioterapi atau terapi membaca merupakan penggunaan buku atau bahan bacaan dalam konseling untuk mendukung perubahan klien. Salah satu manfaat penggunaan biblioterapi yaitu dapat membangun konsep diri siswa karena dengan bahan bacaan yang digunakan pada biblioterapi dapat memberikan informasi, memberikan pengetahuan baru mengenai pengalaman atau situasi yang spesifik, memberikan solusi alternatif mengenai suatu masalah, untuk mensimulasikan diskusi mengenai apa masalah yang sebenarnya, sebagai media mengkomunikasikan nilai atau norma yangberkaitan dengan permasalahan serta membantu siswa paham bahwa ia tak sendiri yang memiliki masalah tersebut. Berdasarkan pemaparan latar belakang di atas, peneliti tertarik untuk melakukan sebuah penelitian guna mengetahui pengaruh teknik biblioterapi untuk membangun konsep diri.

Berdasarkan latar belakang masalah, maka dirumuskan masalah "apakah terdapat pengaruh teknik biblioterapi untuk mengubah konsep diri siswa kelas VIII di SMP Negeri 2 Tangerang?". Penelitian ini bertujuan untuk mengetahui gambaran dan perbedaan konsep diri siswa SMP Negeri 2 Tangerang sebelum dan sesudah penerapan biblioterapi.

\section{KAJIAN TEORETIK BIBLIOTERAPI}

Biblioterapi meruapakan kegiatan dengan media bahan bacaan yang bertujuan untuk mengurangi atau menyelesaikan masalah yang sedang dihadapi oleh seseorang. Salah satu tipe biblioterapi yaitu tipe pendidikan atau humanistik yang merupakan tipe biblioterapi yang dilaksanakan oleh konselor, guru, dan petugas perpustakaan dalam seting pendidikan. Fasilitatornya adalah pimpinan atau manajer kelompok. Adapun partisipan pada terapi pustaka tipe ini adalah orang yang sehat, misalnya siswa.

Tujuan dari tipe ini adalah membantu partisipan untuk mencapai pendidikannya atau mencapai kepuasan dan aktualisasi yang lebih besar. Dalam tipe pendidikaan ini, biblioterapi dapat memperluas pandangan seseorang tentang perbedaan kondisi manusiawi, sehingga diperoleh pandangan yang luas mengenai perbedaan kondisi yang sifatnya manusiawi. Di samping itu, terapi ini juga membantu membuka wawasan adanya nilai-nilai yang beraneka ragam dapat membangun hidup seseorang. Pada akhirnya seseorang dapat memahami berbagai kondisi sosial seperti kemiskinan, prasangka sosial, dan sebagainya serta dapat memberikan tekanan terhadap pola-pola kehidupan 
individu. (Berry, 1994)

Biblioterapi juga bermanfaat untuk mengubah konsep diri individu, meningkatkan motivasi diri, menunjukkan jalan menemukan jati diri, membentuk kejujuran diri, ketahanan emosi dan tekanan mental, menunjukkan bahwa dia bukan satu-satunya orang yang mempunyai masalah, menunjukkan bahwa ada lebih dari satu alternatif penyelesaian masalah, menolong seseorang dengan diskusi masalah, membantu merencanakan sebuah langkah kerja dalammenyelesaikan masalah

Aiex menjelaskan terdapat lima tahap penerapan biblioterapi, baik dilakukan secara perorangan maupun kelompok. (Olsen, 2006)

1. Motivasi. Awali dengan kegiatan pengenalan. Konselor dapat memberikan kegiatan pendahuluan, seperti permainan atau bermain peran, yang dapat memotivasi peserta untuk terlibat secara aktif dalam kegiatan terapi.

2. Membaca. Berikan waktu yang cukup untuk peserta membaca. Konselor mengajak peserta untuk membaca bahanbahan bacaan yang telah disiapkan hingga selesai. Yakinkan, konselor telah akrab dengan bahan-bahan bacaan yang disediakan.

3. Inkubasi. Terapis memberikan waktu pada peserta untuk merenungkan materi yang baru saja mereka baca.

4. Tindak lanjut. Sebaiknya tindak lanjut dilakukan dengan metode diskusi. Lewat diskusi peserta mendapatkan ruang untuk saling bertukar pandangan sehingga memunculkan gagasan baru. Lalu, konselor membantu peserta untuk merealisasikan pengetahuan itu dalam hidupnya.

5. Evaluasi. Sebaiknya evaluasi dilakukan secara mandiri oleh peserta. Hal ini memancing peserta untuk memperoleh kesimpulan yang tuntas dan memahami arti pengalaman yang dialami.

\section{KONSEP DIRI}

Konsep diri sebagai keseluruhan kesadaran tentang diri yang diamati, dialami dan dinilai oleh individu itu sendiri, yang meliputi dunia dalam dirinya maupun hubungannya dengan dunia diluar dirinya. Konsep diri merupakan aspek penting dalam diri seseorang, karena konsep diri merupakan kerangka acuan (frame of reference) yang digunakan oleh individu dalam berinteraksi dengan lingkungannya. (Fitts, 1971).

Terdapat delapan indikator dalam konsep diri, yaitu identitas diri, perilaku diri, penilaian diri, diri fisik, diri moral-etika, diri pribadi, diri keluarga, dan diri sosial. (Fitts, 1971).

Terdapat dua jenis kondep diri, yaitu konsep diri positif yaitu pengetahuan yang luas dan bermacam-macam tentang diri, pengharapan yang realistis, dan harga diri yang tinggi. Konsep diri postiflebih mengarah pada penerimaan diri yang positif, bersifat stabil dan bervariasi. Individu yang memiliki konsep diri positif merupakan individu yang tahu betul siapa dirinya sehingga individu tersebut mampu menerima segala kelebihan dan kekurangan yang ada pada dirinya. Sedangkan konsep diri negatif yaitu pengetahuan yang tidak tepat pada diri sendiri, pengharapan yang tidak realistis, dan harga diri yang rendah. Ada dua tipe konsep diri negatif, yaitu pandangan individu tentang dirinya yang benar-benar teratur dan tidak memiliki perasaan kestabilan dan keutuhan diri, dan pandangan individu tentang dirinya yang benar dan stabil dan teratur, sehingga menciptakan diri yang terlalu keras dan kaku.

Terdapat empat faktor yang berperan dalam pembentukan konsep diri individu, diantaranya yaitu: (Familia, 2006)

1. Faktor kemampuan. Setiap anak mempunyai kemampuan. Oleh karena itu berilah peluang kepada anak agar ia mampu melakukan sesuatu.

2. Faktor perasaan berarti. Pupuklah rasa berarti pada diri anak dalam aktivitas sekecil apapun, jangan dicemooh yang dapat menimbulan perasaan hampa karena perasaan tanpa arti akan 
membentuk sikan negatif.

3. Faktor kebajikan. Bila anak telah memiliki perasaan berarti maka akan tumbuh kebajikan dalam dirinya. Anak merasa lingkungan adalah tempat yang menyenangkan akan menjadi wahana bagi anak untuk berbuat kebajikan.

4. Faktor kekuatan. Pola perilaku berkarakteristik positif memberi kekuatan bagi anak untuk melakukan perubahan yang baik. Kekuatan diri akan membuat anak dapat mencegah dirinya dari perbuatan yang negatif.

\section{PERKEMBANGAN REMAJA}

Masa remaja adalah masa peralihan atau masa transisi dari anak menuju dewasa yang berlangsung kira-kira mulai usia 13 tahun sampai 16 atau 17 tahun. (Hurlock, 1999)

Terdapat sejumlah karakteristik yang menonjol pada usia SMP ini, yaitu (Desmita, 2009):

1. Terjadinya ketidakseimbangan proporsi tinggi dan berat badan

2. Mulai timbulnya ciri-ciri seks sekunder

3. Kecenderungan ambivalensi, antara keinginan menyendiri dengan keinginan bergaul, serta keinginan untuk bebas dari dominasi dengan kebutuhan bimbingan dan bantuan dari orang dewasa

4. Mulai mempertanyakan secara skeptis mengenai eksistensi dan sifat kemurahan dan keadilan Tuhan Reaksi dan ekspresi emosi masih labil

5. Mulai mengembangkan standar dan harapan terhadap perilaku diri sendiri yang sesuai dengan dunia sosial

6. Kecenderungan minat dan pilihan karer relatif sudah lebih jelas

\section{METODOLOGI PENELITIAN}

Penelitian ini dilakukan pada bulan November 2015 di SMP Negeri 2 Tangerang dengan tujuan untuk mengetahui konsep diri siswa sebelum dan sesudah penerapan teknik biblioterapi dan mengetahui pengaruh teknik biblioterapi untuk mengubah konsep diri siswa. Penelitian ini menggunakan metode kuasi eksperimen dengan bentuk Nonequivalent Control Group Design dan menggunakan sampel dengan teknik purposive sampling sebanyak 12 orang siswa yang dikelompokkan menjadi kelompok eksperimen dan kelompok kontrol dengan anggota masing-masing 6 orang.

Kedua kelompok sama-sama diberikan pretest dan posttest dalam bentuk instrumen sebagai acaun pengukuran. Instrumen yang digunakan sebanyak 59 butir yang terdiri dari delapan indikator, yaitu identitas diri, perilaku diri, penilaian diri, diri fisik, diri moral-etika, diri pribadi, diri keluarga, dan diri sosial. Tingkat reliabilitas instrumen sebesar 0,917. Instrumen dibuat dengan skala likert.

Penelitian yang di lakukan dengan penggunaan teknik biblioterapi ini diterapkan dengan bentuk kelompok pada kelompok eksperimen. Bahan bacaan yang digunakan yaitu buku Menjadi Remaja Bahagia karya Andrew Mathews dan Kisah Inspirasi yang diambil dari berbagai sumber. Penelitian dilakukan selama enam pertemuan atau dalam lima tahap.

\section{HASIL DAN PEMBAHASAN}

Berdasarkan hasil pretest terdapat dua belas siswa dengan konsep diri negatif. Enam diantaranya diberikan perlakuan berupa biblioterapi. Perlakuan biblioterapi menunjukkan hasil terdapat lima siswa yang berubah menjadi kategori positif, satu siswa tetap berada pada kategori negatif.

Penelitian dilakukan sebanyak enam kali pertemuan. Pertemuan pertama yaitu tahap motivasi. Tahap ini dilakukan kegiatan perkenalan kegiatan perkenalan kelompok, penetapan jadwal pertemuan, aturan kelompok dan permainan. Pertemuan kedua dilakukan kegiatan membaca dan inkubasi. Pertemuan ketiga dan keempat dilakukan kegiatan tindak lanjut dengan berdiskusi mengenai bacaan yang sudah dibaca pada pertemuan sebelumnya. Pertemuan kelima dilakukan kembali tahap membaca sekaligus inkubasi dan tindak lanjut dengan berdiskusi terkait bacaan yang telah dibaca dengan 
dikaitkan kehidupan sehari-hari anggota kelompok. Pertemuan keenam dilakukan tahap evaluasi, yaitu mengulas pertemuan pertama sampai keenam.

Adapun capaian konsep diri pada kelompok eksperimen dan kontrol sebagai berikut:

\begin{tabular}{lcc}
\multicolumn{3}{c}{ Tabel 1 } \\
\hline \multicolumn{1}{c}{ Kelompok } & Ekperimen & Kontrol \\
\hline \multicolumn{3}{c}{ PRETEST } \\
$\begin{array}{l}\text { Positif } \\
(177 \leq \mathrm{X} \leq 211)\end{array}$ & - & - \\
$\begin{array}{l}\text { Negatif } \\
(143 \leq \mathrm{X} \leq 176)\end{array}$ & 6 & 6 \\
\multicolumn{2}{c}{ POSTTEST } \\
$\begin{array}{l}\text { Positif } \\
(177 \leq \mathrm{X} \leq 211)\end{array}$ & 5 & 1 \\
$\begin{array}{l}\text { Negatif } \\
(143 \leq \mathrm{X} \leq 176)\end{array}$ & 1 & 5 \\
\hline
\end{tabular}

Ada beberapa faktor yang menyebabkan biblioterapi dapat mengubah konsep diri anggota kelompok. Faktor pertama, biblioterapi memberi kesempatan kepada anggota kelompok untuk melihat sudut pandang yang berbeda. Selain itu, anggota kelompok diberi kesempatan untuk mengidentifikasi sikap dan sifat karakter pada bacaan dan kejadian-kejadian penting dalam cerita. Faktor kedua adalah proses kegiatan anggota kelompok dapat melepaskan emosiemosi yang tertahan dalam dirinya selama ini. Anggota kelompok berbagi perasaan dengan anggota kelompok yang lain mengenai pandangan mereka terhadap diri sendiri. Selain itu, ketika mereka mendapatkan pengetahuan bahwa tidak hanya dirinya yang mengalami masalah tersebut dan bahkan banyak orang yang harus berjuang lebih keras dari pada mereka untuk bertahan dikehidupannya, anggota kelompok termotivasi untuk dapat menghadapi masalah yang mereka hadapi dan berfikir bahwa mereka dapat mengubah pandangan dirinya seperti yang ditunjukan oleh karakter yang ada pada bacaan dalam menghadapi masalahnya. Proses ini terdapat pada fase inkubasi dan tindak lanjut yang di dalamnya terdapat kegiatan diskusi. Faktor ketiga adalah karena biblioterapi membantu mereka mengembangkan pemikiran positif terhadap diri mereka. Dinamika kehidupan yang diceritakan pada bacaan membuat mereka berfikir bahwa setiap orang memiliki masalah dan hal itu bukan alasan untuk tidak berprestasi. Proses ini terdapat pada fase evaluasi yang di dalamnya terdapat kegiatan diskusi yang memotivasi anggota satu sama lain dan membantu anggota menyadari dan menerapkan kesadaran diri dan pemahaman diri baru ke situasi kehidupan yang sebenarnya. Tidak berhasilnya satu orang siswa dalam mengubah konsep diri menjadi positif dapat dipengaruhi oleh beberapa faktor, seperti daya tangkap siswa dalam memahami bacaan, teknis pelaksanaan penelitian dan kelas tempat penelitian yang kurang memadai karena situasi sekolah yang sedang mengalami renovasi. Terdapat keterbatasan peneliti juga untuk mendalami permasalahan siswa tersebut karena diperlukan referal penanganan lebih lanjut kepada pihak yang lebih ahli, karena anak tersebut menunjukkan perilaku gagap, sulit menjelaskan isi pikiran dan pendapatnya saat proses treatment. Faktor pengalaman individu juga dapat mempengaruhi hasil treatment. Hubungan interpersonal oleh individu tersebut dengan lingkungannya boleh jadi minim akan penghargaan diri, sehingga individu tetap merasa tidak berarti dan sulit menunjukkan kemampuan diri. Pada kelompok kontrol, terdapat satu siswa yang berada pada kategori positif, dan lima lainnya tetap dalam kategori negatif. Hal ini dapat disimpulkan bahwa siswa yang menerima perlakuan lebih mampu mengubah konsep diri dan mendapat pengaruh positif dari kegiatan biblioterapi.Uji hipotesis yang dilakukan dengan menggunakan Mann Whitney U-Test pada SPSS 20.0 didapat nilai Asymp. Sig sebesar 0,037 yang 
berarti nilai probabilitas lebih kecil dari nilai signifikansi $\alpha 0,05$. Berdasarkan hasil tersebut dapat disimpulkan bahwa $\mathrm{H}_{0}$ ditolak dan $\mathrm{H}_{1}$ diterima, yaitu terjadi perubahan konsep diri yang signifikan setelah diberikan perlakuan. Maka dapat disimpulkan bahwa, terdapat pengaruh biblioterapi untuk mengubah konsep diri siswa SMP Negeri 2 Tangerang.

\section{KESIMPULAN DAN SARAN}

Hasil uji hipotesis dengan menggunakan Mann Whitney U-Test yang dilakukan dengan menggunakan Statistic Product and Service Solution 20.0 for Windows mengungkapkan hasil nilai Asymp. Sig sebesar 0,037. Hipotesis penelitian diuji pada taraf signifikansi $\alpha=0,05$ atau dengan tingkat kesalahan 5\%. Maka nilai Asymp. Sig sebesar 0,037 lebih kecil dari nilai signifikansi $\alpha$ sebesar 0,05 . Berdasarkan hasil tersebut maka dapat disimpulkan bahwa $\mathrm{H}_{0}$ ditolak dan $\mathrm{H}_{1}$ diterima, yang berarti terdapat pengaruh biblioterapi untuk mengubah konsep diri siswa SMP Negeri 2 Tangerang. Saran bagi Kepala Sekolah yaitu mengoptimalkan sarana dan prasarana serta memberikan dukungan kepada guru BK untuk mengikuti pelatihan-pelatihan untuk meningkatkan kompetensi guru BK agar pelayanan bimbingan dan konseling di Sekolah semakin lebih baik. Bagi Guru Bimbingan dan Konseling yaitu membuat program yang berhubungan dengan kegiatan-kegiatan terkait konsep diri siswa, selain itu juga. dapat bekerja sama dengan pustakawan sekolah menyediakan buku-buku sebagai alat penerapan teknik biblioterapi. Bagi MGBK yaitu membuat kajian dan pelatihan mengenai teknikteknik konseling mutakhir yang bertujuan untuk meningkatkan kompetensi diri. Bagi mahasiswa Bimbingan dan Konseling yang akan melakukan penelitian serupa, sebaiknya melakukan penyempurnaan terutama pada tahap persiapan dan proses pelaksanaan, seperti mengetahui besar minat anggota kelompok terhadap kegiatan membaca, bahan bacaan yang digunakan sebaiknya dikonsultasikan terlebih dahulu dengan pustakawan, pengadaan fasilitas penunjang penelitian yang sangat krusial seperti ruangan yang kondusif dengan standar kelayakan, dan pengalokasian waktu yang memadai untuk meningkatkan efektivitas penerapan teknik biblioterapi.

\section{DAFTAR PUSTAKA}

Berry, M.H. (1994). Biblio/poetry therapy: The interactive process: A Handbook. Illinois: North Star Press of St Cloud.

Desmita. (2009). Psikologi Perkembangan Peserta Didik. Bandung: Remaja Rosdakarya.

Eliasa, E.I.(n.d.). Biblioterapi sebagai sebuah metode tindakan yang bermakna. UNY

Familia, P. (2006). Konsep Diri Positif, Menentukan Prestasi Anak. Yogyakarta: Kanisius.

Fitts, W.H. (1971). The Self Concept And Actualization. Los Angeles: Wilshire Boulevard

Hurlock. (1999). Psikologi Perkembangan: Suatu Pendekatan Sepanjang Rentang Kehidupan. Jakarta: Erlangga.

Olsen, M. A. (2006). Bibliotherapy: School Psychologists' Report of Use and Efficacy. Provo: Brigham Young University 
